\title{
PREVALENCE OF INCIDENTAL GALLBLADDER CANCER IN A TERTIARY-CARE HOSPITAL FROM PERNAMBUCO, BRAZIL
}

\author{
Euclides Dias MARTINS-FILHO, Thales Paulo BATISTA, Flávio KREIMER, \\ Antonio Cavalcanti de Albuquerque MARTINS, Tiago Cavalcanti IWANAGA \\ and Cristiano de Souza LEÃO
}

Received 30/10/2014 Accepted 16/3/2015

\begin{abstract}
Background - Gallbladder cancer is sometimes incidentally uncovered following cholecystectomy for gallstones diseases. The supposed highly variable prevalence of incidental gallbladder cancer through our country is unknown. Objective - To explore the prevalence of incidental gallbladder cancer in our tertiary-care hospital. Methods - A cross-sectional study was carried out on patients who consecutively underwent cholecystectomy due to gallstones disease at Faculdade Pernambucana de Saúde, Instituto de Medicina Integral Professor Fernando Figueira - FPS/IMIP, from January, 2007 to December, 2010. Data on incidental gallbladder cancer patients were explored for prevalence estimation and description of our experience with the management of this malignancy. Results - Our analysis involved 2018 patients with a marked predominance of women $(\mathrm{n}=1.697 ; 84.1 \%)$ over men $(\mathrm{n}=321 ; 15.9 \%)$. The 3-year prevalence estimate of $0.34 \%$ was recorded for incidental gallbladder cancer in our sample. Regarding tumor staging, there were $1 \mathrm{~T} 1 \mathrm{a}, 1 \mathrm{~T} 1 \mathrm{~b}$, and $5 \mathrm{~T} 2$ adenocarcinoma tumors. Laparoscopic cholecystectomy alone was performed for the T1a tumor, and additional radical surgery was performed in five others. One patient presented metastatic disease at the time of repeat surgery. The final pathology revealed residual/additional disease in all $\mathrm{T} 2$ tumors after radical surgery whereas the T1b patient underwent a salvage Whipple's procedure due to a secondary distal cholangiocarcinoma. The patient with T1a tumor is alive after 3-year follow-up but all of the others died because of disease recurrence/progression up to 12 months. Conclusion - This study confirms the poor prognosis of Gallbladder cancer even when incidentally diagnosed following cholecystectomy and supposes a 3-year prevalence estimate of $0.34 \%$ for incidental gallbladder cancer in our Center from Pernambuco State, Brazil.
\end{abstract}

HEADINGS - Gallbladder neoplasms. Cholecystectomy. Incidental findings.

\section{INTRODUCTION}

Gallbladder cancer (GBC) is a rare neoplasm in general but is also the most common malignancy of the biliary tract, accounting for $80 \%-95 \%$ of these cancers worldwide $^{(7)}$. The global rates for GBC exhibit striking variability, reaching epidemic levels for some regions and ethnicities. These rates are extraordinarily high in Latin America and Asia ${ }^{(3,7)}$ and tend to particularly afflict indigenous populations ${ }^{(7)}$. In Brazil, an estimated 4,049 new cases of GBC was reported to be diagnosed in 2012 $2^{(3)}$; however, the rates of GBC among the heterogeneous population from the diferent states and regions of this large country was not completely described yet.
A satisfactory outcome of patients suffering from GBC is critically dependent on an early diagnosis and most of these patients are usually faced with a poor prognosis due to diagnosis at later stages ${ }^{(7)}$. On the other hand, some of GBCs have been uncovered fortunately as an incidental gallbladder cancer (iGBC) at the time of cholecystectomy due to cholelithia$\operatorname{sis}^{(6,7,14,15,17)}$. Since discovering of GBC incidentally may offer the best opportunity for a curative approach in this aggressive neoplasm, the current study aimed to explore the prevalence of iGBC in our tertiary-care hospital from the State of Pernambuco (Brazil), supposing a highly variable prevalence through our country. Additionally, we also describe our experience with the management of these cancers in our Center.

Declared conflict of interest of all authors: non

Disclosure of funding: no funding received

Departamento de Cirurgia, Faculdade Pernambucana de Saúde, Instituto de Medicina Integral Professor Fernando Figueira - FPS/IMIP, Recife, PE, Brasil.

Correspondence: Thales Paulo Batista. R. Pio IX, 435. Ed. Maria Raquel, ap. 701 - Madalena - CEP: 50710-260 - Recife, PE, Brasil. E-mail: t.paulo@bol.com.br 


\section{METHODS}

A cross-sectional study was carried out on patients who consecutively underwent either open or laparoscopic cholecystectomy due to gallstones disease at Faculdade Pernambucana de Saúde, Instituto de Medicina Integral Professor Fernando Figueira - FPS/IMIP, from January, 2007 to December, 2010. Using our own database, we reviewed the patient's medial records and the corresponding final histopathological studies of the gallbladder specimens mainly in order to explore the prevalence of iGBC in the Pernambuco of State, Brazil. We limited our study to patients with complete data in their medical records while patients with any preoperative suspicious of GBC were excluded. All procedures complied with the standards of the current Brazilian ethical guidelines and our Ethics Research Committee approved the study design (CAAE 0298.0.099.000-09).

\section{RESULTS}

Two thousand and eighteen patients consecutively underwent cholecystectomy for gallbladder disease at our center from January, 2007 to December, 2010. Most of them received laparoscopic cholecystectomy and a marked predominance of women $(n=1.697 ; 84.1 \%)$ over men $(n=321$; $15.9 \%)$ was also found. Herein, $10(0.49 \%)$ patients were initially found as presenting iGBC, but review of patient's medical records revealed some preoperative suspicious of GBC in three of them, which were excluded from our final prevalence estimation. Thus, a 3-year prevalence estimate of $0.34 \%$ was recorded for $\mathrm{iGBC}$ in our sample.

Cholecystectomy was performed as laparoscopic cholecystectomy $(n=2)$ or open surgery $(n=5)$ due to symptomatic gallstones disease in one (14.3\%) male and six $(85.7 \%)$ females patients with a median age of 57 years (range 46-69). The histological examination found adenocarcinoma as the typical histology in all of iGBC. Regarding tumor staging, there were one T1a, one T1b, and five T2 tumors. Laparoscopic cholecystectomy alone was performed for the T1a tumor, and additional radical surgery (i.e.: resection of the liver segments $4 \mathrm{~b} / 5$ plus regional lymphadenectomy) was performed in five others. One patient presented metastatic disease at the time of reoperation. The final postoperative histopathological studies from the re-resection specimen revealed residual/additional disease in all the patients with $\mathrm{T} 2$ tumors who underwent radical surgery, whereas the $\mathrm{T} 1 \mathrm{~b}$ patient underwent a salvage Whipple's procedure due to a secondary distal cholangiocarcinoma. The patient with T1a tumor is alive after 3-year follow-up but all of the others died because of disease recurrence/progression up to 12 months. 5FU-based chemotherapy $(n=3)$ or best support care were offered after relapses as appropriated.

\section{DISCUSSION}

Gallstones are a common disease ${ }^{(4,5,11)}$ and represent an important risk factor for $\mathrm{GBCs}^{(7)}$. Eventually, some of these tumors are found at the time of cholecystectomy ${ }^{(7)}$, which may offer the best opportunity for an early diagnosis and curative approach as this malignancy often progresses silently up to a late diagnosis. Accordingly, we considered important to present our experience with the management of iGBC and to provide an estimation of how prevalent is the incidental diagnosis of this rare neoplasm in our State. In contrast to previous report of 2.3\% from other State of our region (Maranhão, Northeast Brazil) ${ }^{(17)}$, only $0.34 \%$ of patients were found as presenting iGBC in our sample. Worldwide, such iGBC have been detected histologically in about $0.3 \%-3 \%$ of cholecystectomies performed for cholelithiasis $^{(7)}$.

Cholecystectomy alone - mainly laparoscopic cholecystectomy - is an adequate treatment for pT1a tumors whereas additional radical surgery plus lymph node dissection might be needed to achieve a tumor-free surgical margin for pT2 and pT3 patients ${ }^{(2,6,8,10,13,14,17)}$. Herein, an aggressive reoperation for iGBC is usually warranted as the majority of patients have residual disease after the radical surgery ${ }^{(9,14)}$, as we noticed in our study. Although common duct resection does not yield a greater lymph node count or improved survival ${ }^{(6)}$, it should be performed at the time of reoperation for patients with positive cystic duct margins because over one-third will have residual disease in the common bile duct ${ }^{(14)}$. Similarly, we also have favored a radical approach for those $\mathrm{pT} 1 \mathrm{~b}$ tumors in order to improve survival outcomes.

Despite there could be an association between some histological alterations of gallbladder and cancer, the perfect understanding of gallbladder carcinogenesis still requires further investigation ${ }^{(12,16,18)}$, and the need for routine histological examination of gallbladder has also been questioned in order to reduce the burden on pathology departments and significantly saving $\operatorname{cost}^{(1)}$. Thus, whether a routine or selective histological examination is equally beneficial for patients who underwent cholecystectomy performed for gallstones disease remains unclear. In these settings, a selective policy rather than routine histological examination might to be considered and the pathological study be heightened postoperatively when the surgeons are performing or converting from laparoscopic to open surgery, and when patients are older or female, and have an Ethnic predilection (i.e.: indigenous populations, particularly from North and South America), elevated alkaline phosphatase levels or a thickened-wall gallbladder ${ }^{(1,15)}$.

The main limitation of this study is related to our retrospective approach that mitigated the analysis of some clinical variables and risk factors. However, a major scientific merit of this report was to explore the prevalence of iGBC using 
a large sample from Northeast Brazil, where the prevalence of this malignancy is supposed to be highly variable due to the geographic and ethnic variance through our country. Moreover, our institution currently works as a comprehensive tertiary care center with a high surgical and oncological caseload that serves patients of the public health system from different regions of the State, including health programs for assistance of our indigenous populations. To our best knowledge, this is the first study in these settings, and our single-center database probably offers a representative sample of patients from the Pernambuco State.

In conclusion, this study confirms the overall poor prognosis for patients suffering of GBC, even when incidentally uncovered following cholecystectomy being performed for gallstones diseases. Also, we suppose a 3-year prevalence estimate of $0.34 \%$ for iGBCs in our Center from the Pernambuco State, Brazil.

\section{Authors' contributions}

Study concept and design: Martins-Filho ED. Acquisition of data: all authors. Analysis and interpretation of data: all authors, mainly Batista TP and Martins-Filho ED. Drafting of the manuscript: Batista TP. Critical revision of the manuscript for important intellectual content: all authors. Administrative and material support: Martins ACA and Leão CS. Study supervision: Leão CS.

Martins-Filho ED, Batista TP, Kreimer F, Martins ACA, Iwanaga TC, Leão CS. Prevalência do câncer incidental de vesícula biliar em um hospital terciário de Pernambuco, Brasil. Arq Gastroenterol. 2015,52(3):247-9.

RESUMO - Contexto - O câncer de vesícula biliar ocasionalmente é descoberto após colecistectomias realizadas para tratamento da colelitíase. No entanto, a heterogênica prevalência de seu diagnóstico incidental é desconhecida entre as diferentes regiões de nosso país. Objetivo - Explorar a prevalência do câncer incidental da vesícula biliar em nosso centro terciário de saúde. Métodos - Realizou-se estudo de coorte retrospectivo incluindo pacientes consecutivamente submetidos a colecistetomias para tratamento da colelitíase na Faculdade Pernambucana de Saúde, Instituto de Medicina Integral Professor Fernando Figueira - FPS/IMIP, de janeiro de 2007 a dezembro de 2010. Os dados dos pacientes com câncer incidental da vesícula biliar foram analisados visando estimar sua prevalência e descrever a experiência do serviço no manejo desta neoplasia. Resultados - Esta análise envolveu 2018 pacientes, com marcada predileção do gênero feminino $(n=1,697 ; 84,1 \%)$ sobre o masculino $(n=321 ; 15,9 \%)$. A prevalência em 3 anos para o câncer incidental da vesícula biliar foi estimada em $0,34 \%$ em nossa casuística. Ao estadiamento patológico inicial, observou-se um caso T1a, um $\mathrm{T} 1 \mathrm{~b}$, e cinco T2, todos com diagnóstico histológico de adenocarcinoma. Colecistectomia laparoscópica isoladamente foi realizada para o tumor T1a, enquanto a complementação cirúrgica radical foi realizada em outros cinco. Em um caso, evidenciou-se doença metastática à reoperação. O estudo histopatológico após a cirurgia radical revelou doença residual/adicional em todos os tumores T2 e um paciente (T1b) foi submetido ao resgate cirúrgico (cirurgia de Whipple) para tratamento de colangiocarcinoma distal secundário. O caso estadiado como T1a está vivo após 3 anos de acompanhamento ambulatorial, enquanto todos os outros faleceram por recidiva/progressão neoplásica em até 12 meses. Conclusão - Este estudo confirma o mal prognóstico do câncer de vesícula biliar mesmo quando incidentalmente descoberto após colecistectomias e pressupõe a prevalência em 3 anos de $0,34 \%$ para seu diagnóstico incidental em nosso centro terciário de saúde.

DESCRITORES - Neoplasias da vesícula biliar. Colecistectomia. Achados incidentais.

\section{REFERENCES}

1. Bazoua G, Hamza N, Lazim T. Do we need histology for a normal-looking gallbladder? J Hepatobiliary Pancreat Surg. 2007;14(6):564-8.

2. Costa SR, HortaSH, Miotto MJ, Costas MC, Godinho CA, Henriques AC [Central inferior bisegmentectomy $(\mathrm{S} 4 \mathrm{~B}+\mathrm{S} 5)$ for gallbladder carcinoma treatment: a series of seven resectable cases]. Arq Gastroenterol. 2008;45(1):73-81.

3. Ferlay J, Soerjomataram I, Ervik M, Dikshit R, Eser S, Mathers C, et al. GLOBOCAN 2012 v1.0, Cancer Incidence and Mortality Worldwide: IARC CancerBase No. 11 [Internet]. Lyon, France: International Agency for Research on Cancer; 2013. [accessed 2014 May 27]. Available from: http://globocan.iarc.fr.

4. Ferreira AC, Mauad-Filho F, Mauad FM, Barra DA, Mattos RL, Jorge FI. [Asymptomatic gallstones in women: epidemiological and clinical aspects]. Rev Col Bras Cir. 2006;33(4):235-41.

5. França L de A, Santos ET, Carvalho AM, Silva AM, Rocha A. Prevalence of biliary lithiasis in cirrhotics: necropsy evaluation. Arq Gastroenterol. 1994;31(3):92-6.

6. Fuks D, Regimbeau JM, Le Treut YP, Bachellier P, Raventos A, Pruvot FR, et al. Incidental gallbladder cancer by the AFC-GBC-2009 Study Group. World J Surg. 2011;35(8):1887-97.

7. Hundal R, Shaffer EA. Gallbladder cancer: epidemiology and outcome. Clin Epidemiol. 2014;6:99-109. eCollection 2014.

8. Ishak G, Ribeiro FS, Costa DS, Bahia LAC, Dias EM, Assumpção PP. [Gallbllader cancer: 10 years of experience at an Amazon reference hospital]. Rev Col Bras Cir. 2011;38(2):100-4.

9. Lendoire JC, Gil L, Duek F, Quarin C, Garay V, Raffin G, Rivaldi M, Alejandra $\mathrm{O}$, Imventarza $\mathrm{O}$. Relevance of residual disease after liver resection for incidental gallbladder cancer. HPB (Oxford). 2012;14(8):548-53.
10. Manterola C, Vial M, Roa JC. Survival of a cohort of patients with intermediate and advanced gallbladder cancer treated with a prospective therapeutic protocol. Acta Cir Bras. 2010;25(3):225-30.

11. Mantovani M, Leal RF, Fontelles MJ. [Incidence of cholelithiasis: a necropsy study performed in Campinas university hospital, SP]. Rev Col Bras Cir. 2001;28 (4):259-63.

12. Meirelles-Costa AL, Bresciani CJ, Perez RO, Bresciani BH, Siqueira SA, Cecconello I. Are histological alterations observed in the gallbladder precancerous lesions? Clinics (Sao Paulo). 2010;65(2):143-50.

13. Pais-Costa SR, Farah JFM, Artigiani-Neto R, Franco MIF, Martins SJ, Goldenberg A. [Gallbladder adenocarcinoma: evaluation of the prognostic factors in 100 resectable cases in Brazil]. Arq Bras Cir Dig. 2012;25(1):13-9.

14. Pawlik TM, Gleisner AL, Vigano L, Kooby DA, Bauer TW, Frilling A, et al Incidence of finding residual disease for incidental gallbladder carcinoma: implications for re-resection. J Gastrointest Surg. 2007;11(11):1478-86.

15. Pitt SC, Jin LX, Hall BL, Strasberg SM, Pitt HA. Incidental Gallbladder Cancer at Cholecystectomy: When Should the Surgeon Be Suspicious? Ann Surg. 2014;260(1):128-33.

16. Rocha AO, Coutinho LMB, Leboute LDP, Scholl JG. [Immunohistochemical expression and prognostic value of the p53 protein in gallbladder carcinoma: a 60-case study]. J Bras Patol Med Lab. 2004;40(6):403-10.

17. Torres OJM, Caldas LRA, Azevedo RP, Palácio RL, Rodrigues MLS, Lopes JAC. [Cholelithiasis and gallbladder cancer]. Rev Col Bras Cir. 2002;29(2):88-91.

18. Veloso MGP, Rodrigues DV. Gallbladder carcinoma: clinicopathological study of 24 cases. J Bras Patol Med Lab. 2011;47(4):439-44. 